\title{
THE POTENTIAL OF DIGITAL PLATFORMS IN REVITALISING THE LIVESTOCK SYSTEM IN RURAL ZIMBABWE
}

\author{
Leon Tinashe Gwaka \\ Institute for Social Development \\ University of the Western Cape \\ South Africa \\ tinashegwaka@gmail.com
}

\begin{abstract}
Livestock contribute towards household food security in rural communities through income generation and provision of animal-source food. However, livestock system are fragile for example, in Zimbabwe, communities face challenges such as fewer buyers, poor infrastructure, and information asymmetry when selling livestock. Emerging digital platforms promise opportunities to address these challenge but only anecdotal evidence exist. This paper uses data from Beitbridge to explore the potential of digital platforms to revitalise the livestock auction system. Study findings show that digital platforms are designed with affordances which can help overcome challenges within the livestock system. However, these digital platforms are also fraught with hidden complexities such as power dynamics. Thus, despite digital platforms' affordances, their design inherently extends beyond technical functions. Therefore, there is an urgent need for discussions exploring the contrast between affordances and complexities to enable target users to make informed decisions on the adoption and use of digital platforms.
\end{abstract}

\section{Keywords}

Digital platforms, digital auction, livestock systems, Zimbabwe

\section{INTRODUCTION}

Historically, agriculture has been a core livelihood activity for many societies across the world, with a higher share of Gross Domestic Product in most African countries (Thirtle, Lin \& Piesse, 2003). While specialized farming has gained traction in recent years, mixed farming which combines livestock and crop production has been the more common practice, especially among smallholder farmers. However, the choices of the predominant agricultural system practiced in communities are often driven by several factors such as culture and geographic location. For example, in Zimbabwe, the Beitbridge district is located in the natural climatic region (V) which receives an average rainfall of less than 500mm per season, thus, is less suitable for crop production resulting in most households opting to engage in livestock production (Mugandani, Wuta, Makarau \& Chipindu, 2012). Further to this, the global agenda (led by government or non-government), coupled with national development plans, also play a key role in determining agricultural systems to prioritise. In the context of this study for instance, the $43^{\text {rd }}$ Committee on World Food Security (CFS) convention ratified livestock as critical towards the fight against global food insecurity (CFS, 2016) and this has resulted in growing interests towards global livestock systems.

In most developing countries, livestock is important to livelihoods, mainly in rural areas, contributing to food availability, income generation and playing sociocultural roles. For countries such as Botswana, livestock is of economic significance, contributing up to $57 \%$ of the country's Gross Domestic Product 
(Temoso, Villano \& Hadley, 2016). Despite this, global livestock systems, mainly in developing countries face many challenges threatening their sustainability. ${ }^{1}$ Studies available such as Mavedzenge, Mahenehene, Murimbarimba, Scoones and Wolmer (2008), provide evidence showing the fragility of livestock systems, particularly in rural communities. These studies argue that livestock systems' fragility mainly stems from the poor overall structure, particularly relating to the market dynamics. In Zimbabwe for instance, in the early 1990s, livestock marketing was formally facilitated by the Cold Storage Commission (CSC), a commission formed during the colonial period and later inherited by the independent government as a parastatal following the attainment of independence in 1980 (Mlambo, 1996). Through the CSC, all the livestock buying and selling activities were centralized (Mavedzenge et al., 2008) and in this way, the Zimbabwe's beef sector was highly competitive even in the export markets. However, at the onset of the economic crisis in Zimbabwe, policy transformations which recommended the adoption of Economic and Structural Adjustment Program (ESAP) led to the subsequent privatisation of the CSC and ultimately, the role of CSC in livestock marketing became insignificant, permanently transforming the livestock marketing landscape. In years preceding this transformation, formal livestock auctioning ceased to exist in most rural areas (e.g. at the time of this study, only 10 rural districts out of 60 were conducting formal livestock auction) creating an opportunity for unscrupulous livestock traders to fill this gap. ${ }^{2}$ Characteristically, these traders often offer suboptimal prices to smallholder farmers (cf. Herald, 2017; Gwaka, 2017). In addition to this, the macroeconomic problems in Zimbabwe, climate change and poor infrastructure further contribute to rural communities' failure to achieve optimal returns from their agricultural produce, including livestock, evincing an urgent need for transformation of the livestock markets in rural communities (Barrett, Christian \& Shiferaw, 2017; Mavedzenge et al., 2008).

Solving problems faced within rural communities often attracts interests from multiple disciplines including computer science and social sciences (Oliver et al., 2018). One discipline that has increasingly become integral in solving complex societal challenges is the Information and Communication Technology (ICTs). This has resulted in the establishment of the ICT for development discipline, also referred to as ICT4D, which focuses on the application of ICTs in different sectors including education, health and agriculture (Heeks, 2014; Walsham, 2017). Despite large investments in ICT projects and research over the years, the contributions of ICTs to development remain contested (Quaglio et al., 2016). ${ }^{3}$ On the contrary, there are more investments in recent years and one mechanism which is increasingly becoming popular is the use of digital platforms, also known as sharing economy (Avram et al., 2017). In the context of this study, particularly livestock marketing, there are suggestions that emerging technologies (digital platforms) can transform the structure of "place, practices and circumstances" (Avram et al., 2017). Against the challenges faced in rural markets, and the urgent need for transforming these rural markets, the potential benefits which can be derived from adopting digital platforms (electronic markets) are difficult to dismiss (Malekovic, Goutas, Sutanto \& Galletta, 2019). However, the urgency of the situation creates a danger of adopting tools which can further exacerbate problems within the system. For instance, while digital platforms are credited with easing complex transactions and processes, their very existence, functioning and design often embed hidden meanings which should trigger "fundamental questions around the perils of their design and use" (Avram et al.,

\footnotetext{
${ }^{1}$ Sustainability is complex to define, but it is mainly addressed in terms of economic, environmental, and sociocultural terms. However, Marandure, Makombe, Dzama, Hoffmann, Mapiye, (2018) argue that sustainability should be viewed in context.

${ }^{2}$ Discussions with Chief Executive Officers of Beitbridge and Rushinga Rural District Councils.

${ }^{3}$ Here, in line with Avgerou (2010), development is considered in broad sense since it is a contested term.
} 
2017). In a way, the purported benefits of integrating digital platforms within a value chain may have other undesirable effects. Evidently, there is need for evidence on the moderated impacts of digital platforms to better inform decision-making among target users and policy makers.

To this end, this study, drawing from canonical techno-political thinkers such as Winner (1980) and Star (1999), asks the following question: What is the potential of digital platforms to revitalise the neardefunct formal livestock auctioning systems in rural Zimbabwe? The study answers this question by firstly characterising the livestock system in the study area to provide an overview of the current state of the livestock system. Following this, the study then explores the potential of the digital platforms in light of the prevailing challenges identified. The study achieves this through data collected from fieldwork in Beitbridge - Zimbabwe. The main argument of the study is that, despite the affordances of digital platforms, the design of digital platforms inherently extends beyond technical functions. These platforms are socio-political in nature, motivated by capitalistic ideologies more than the need to solve problems (cf. de Reuver, Sorensen \& Basole, 2017). To an extent, this is clarified in van Doorn's (2018) suggestion that the goal of any digital platform is nothing more than power itself. The study findings presented show that some digital platforms were rejected based on this idea, but users remain unaware of the broader issues of power dynamics, capitalism and other complexities within digital platforms. Therefore, there is need for urgent discussions on these critical issues which in turn can help users make informed decision and also, challenge the regulators to think about future regulations which may be necessary on digital platforms. The remainder of the paper is structured as follows; an overview of the Beitbridge livestock system is provided in the next section to obtain a contextual understanding of the study area. This is followed by the theoretical framework on which the study is framed and the research methods. The study results follow before the discussion and conclusion of the study.

\section{STUDY CONTEXT AND OVERVIEW OF STUDY AREA}

Beitbridge district is in Matabeleland South Province, one of the eight rural provinces in Zimbabwe (Vogt et al., 2015). The area is in agro-ecological region V (see Figure 1) and the general environmental conditions in the study area are not ideal for crop production, thus, most of the households rely on livestock for income, food and other services. In addition to being reliable source of household food and income, livestock also form part of household capital and risk management strategy. 


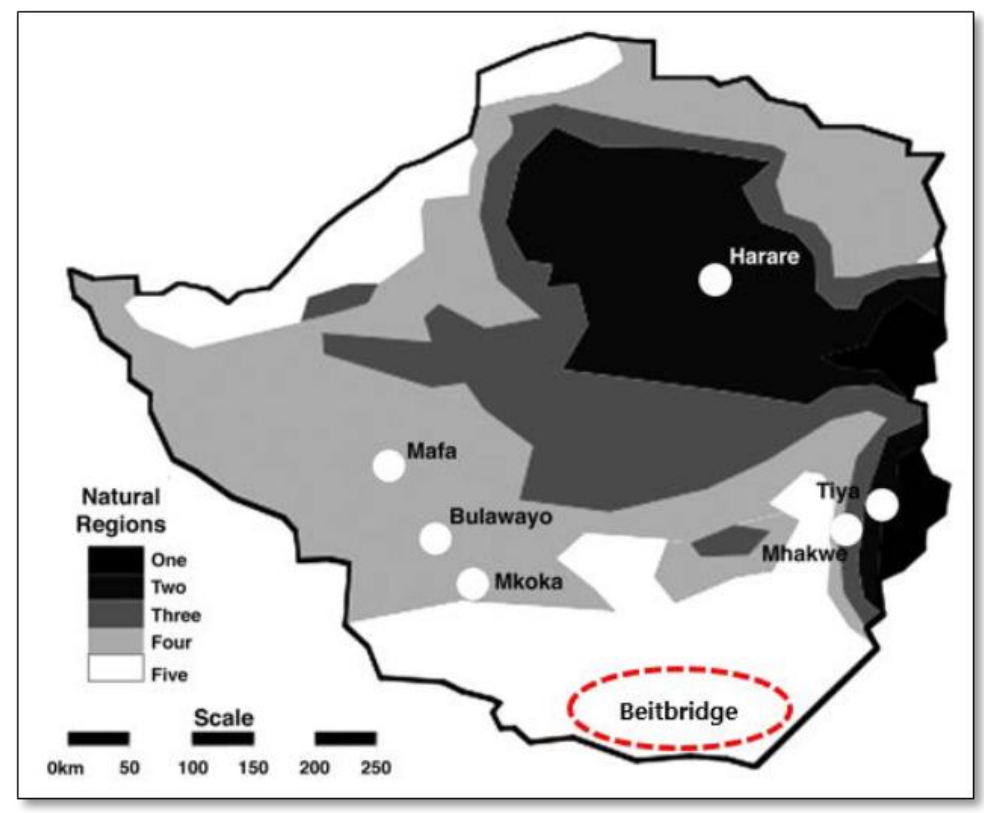

Figure 1: Map of Zimbabwe showing natural regions and location of the study area

Source: Patt, Suarez and Gwata (2005)

Despite the importance of livestock in the livelihoods of smallscale farmers in Beitbridge, the livestock system faces several challenges. For instance, Gwaka (2017) demonstrates that farmers in the study area are failing to obtain optimal prices for the livestock due to failure to participate in attractive markets. Other challenges are not unique to the study area. Descheemaeker et al. (2018) show that climate change impacts the sustainability of the livestock system while the International Fund for Agricultural Development (IFAD) (2016) suggests that a lack of and/or poor infrastructure affects local value chains including the livestock system. Further to this, Notenbaert et al. (2017:154) posit that the fragility of the livestock system is likely to continue with system actors demonstrating inability to select, target and prioritize interventions. To address this, it is important to develop deep insights on the livestock system. since livestock systems are classified as socio-ecological systems, they are complex to understand and Ison, Maiteny and Carr (1997) recommend using the systems thinking approach to achieve this. Ostrom's Socio-Ecological Systems (SES) (Ostrom, 2009) also follows a systems thinking approach and Marshall (2015) adopted the SES framework to explore a livestock system in Cambodia. The SES framework suggests that a socio-ecological system is made up of primary and secondary attributes which interact to produce outcomes. This study argues that the state of the livestock system can be explained using system attributes presented in Table 1.

\begin{tabular}{|l|l|}
\hline System attribute & Extended analysis \\
\hline Resource System & $\begin{array}{l}\text { Exploring how the system location impacts the sustainability of } \\
\text { the livestock system, } e . g \text {. proximity to markets. } \\
\text { Identifying the human constructed facilities available in the } \\
\text { community, with a specific focus on the infrastructure. }\end{array}$ \\
\hline Resource Units & $\bullet \begin{array}{l}\text { Determining the economic value attached to livestock by } \\
\text { different livestock system actors, as well as establishing the } \\
\text { marketing characteristics of livestock in the study area. }\end{array}$ \\
\hline Governance System & $\bullet \begin{array}{l}\text { Exploring the coordination among the rule making } \\
\text { organisations, e.g. including public and private sectors. }\end{array}$ \\
\hline
\end{tabular}




\begin{tabular}{|l|l|}
\hline Actors & $\begin{array}{l}\text { Identifying the number of actors in the study area's livestock } \\
\text { system. These actors will include individuals (key groups) and } \\
\text { institutions. }\end{array}$ \\
\hline Social, Economic \& Political (exogenous) & $\begin{array}{l}\text { Exploring the use (or non-use) of technology by the actors in } \\
\text { the livestock system. }\end{array}$ \\
\hline $\begin{array}{l}\text { Understanding the influence on broader socio-economic and } \\
\text { political dynamics on the livestock system }\end{array}$ \\
\hline
\end{tabular}

Table 1. Applying Ostrom's SES to analyse the Beitbridge livestock system

In the context of Beitbridge, the location (distance to markets) of the Resource System, and a lack of human constructed facilities (such as roads and digital infrastructure) negatively impact the number of buyers [number of actors] participating in the livestock system. Furthermore, the socio-economic characteristics (generally poor households) of the livestock farmers coupled with the marketing characteristics of the livestock also influence the negotiation process. In addition, poor coordination among governance structures is contributing to poor or non-existence of robust policies. This is further complicated by the on-going socio-economic and political instability within the country. Against the context provided, Prockl, Bhakoo and Wong (2017) believe that value chains such as livestock systems can be supported by electronic innovations to overcome the challenges inherent in these systems. Thus, technological innovations, including digital platforms, can be integrated in the value chain (Vanclay, Russell \& Kimber, 2013). While most farmers in the study area are considered poor (in economic sense) Kuriyan, Nafus and Mainwaring (2012) promote the poor-as-consumer model arguing the need to design technologies to serve the needs of the poor. However, Toyama cautions that technology only amplifies human intent and as such, the introduction of ICTs into fragile value chains is no guarantee of improving these value chains unless value chain actors are keen to improve the value chain. Based on this, it is prudent to argue that digital technologies can be developed for poor communities to improve value chain/system attributes. However, value chain actors need to play a role to realise that.

\section{CONCEPTUAL FRAMEWORK}

This study investigates the potential of digital platforms to revitalise the livestock systems in rural communities. Based on literature, this study considers digital platforms, metaphorically, as "two sides of a coin" (Figure 2). On one side, there are digital platform designers and providers who have different roles (design, provide and maintain) and on the other side, target users adopt, use or reject. Within these platforms, there are complex relationships and interactions. It is critical to explore the roles and interests of both target users and technology developers (cf. Avgerou, Hayes \& La Rovere, 2016). In the next sections, each of the three constructs is closely examined.

\section{Digital platforms and livestock system}

The study area's livestock system is fragile and like other rural districts in Zimbabwe, the auction system is near-defunct. Despite this, digital platforms are emerging which can potentially play a key role to revatilise system. Examples of these platforms include mobile money service providers (Ecocash), agricultural information providers (E-Mkambo) and livestock information systems providers (Remote Livestock Marketing System). However, these digital platforms are complex, particularly how they "intertwine with institutions, markets and technologies" (de Reuver et al., 2017) thus, understanding 
them requires critical thinking which extends beyond techno-deterministic approaches (cf. Winner, 1980; Star, 1999). This is in line with Winner's (1980:121) suggestion that, "[a]t issue is the claim that the machines, structures, and systems of modern material culture can be accurately judged not only for their contributions of efficiency and productivity, not merely for their positive and negative ... side effects, but also for the ways in which they can embody specific forms of power and authority"

Building on existing critical perspectives, this study postulates that digital platforms are potentially new controlled environments and "apparatus of power [which] can exert control over us" as we use them (Crain, 2013: np). Additionally, drawing from Deleuze's (1992) societies of control perspective, the study argues that technological evolutions, which include the emergence digital platforms, may also resemble a "mutation of capitalism" (p.6). Deleuze (1992) argues that societies are controlled spaces and digital innovations (also referred to as control tools) evolve to match each generation. Thus, while digital platforms appear to provide solutions to complex challenges, little is known on whether these digital platforms are also creating illusions of freedom. Aptly stated, in using digital platforms "Unforeseen consequences and unintended behaviors can easily occur [and] there are lots of "unknown unknowns" and chaotic dynamics (Negash, Musa, Vogel \& Sahay, 2018:192).

\section{Digital platform designers and providers}

Another dimension of the digital platforms (Figure 2) is the designers and providers. van Stam (2017) is concerned that for Africa, most technologies, including digital platforms, are supplied by western entities whose understanding of and knowledge on local contexts is limited. To an extent, this raises questions on their motivations for developing these technologies (ibid). In recent times, start-ups developing digital platforms (mainly apps) are a new form of entrepreneurship, some managing to amass many users within short periods. Innovations spun across the different societal sectors including agricultural systems. However, in line with this study's primary question, Kuriyan et al. (2012:2) note that "the aims and claims of many market interventions to serve the poor are broad, the assumptions behind them are often unarticulated, untested, and open to challenge" Often, interests of digital platform designers and providers are hidden (unknown to target users). For instance, van Doorn (2018) argues that platform designers and providers are interested in accumulating power and control. Using Facebook as an illustration, Fuchs and Sevignani (2013:259) support this notion by showing that:

“... Facebook users do not just satisfy [their] needs, but also serve Facebook's profit interests. Facebook turns personal profile data, usage behaviour data from the Facebook platform and other platforms, social network data and content data (images, videos, messages, postings) into data commodities"

Given the foregoing, this study argues that while digital platforms designers and providers play critical roles of designing, providing and maintaining platforms, their value propositions (technology affordances) need to be considered in light of value capture dimension (Täuscher \& Laudien, 2018), which, often, extends beyond monetary form to include power and control (Barrett, Oborn \& Orlikowski, 2016).

\section{Target users}

Target users is the third construct of the conceptual framework and in this study, these are livestock system actors: livestock buyers, livestock farmers, relevant government departments and other 
stakeholders. As indicated in figure 2, target users are interested in the platforms' affordances and their roles include adopting, using and/or rejecting the digital platforms. The ubiquity of technology, mainly mobile phones, is drawing many users, including those with limited affinity of technology, to digital platforms. While many studies including Rey-Moreno (2015) show that digital services remain expensive in rural communities, Kuriyan et al. (2012) provide a different thinking by mapping these marginalised individuals, the "poor", as "consumers". Kuriyan et al demonstrate how these consumers are ready and willing to pay for digital services. However, beyond financial concerns, digital platforms embody other characteristics unknown to consumers e.g. relating to issues of power and control. In addition, Harris (2016) thinks that most technological innovations have failed to serve the needs of the poor. It is in this context that the study argues the need to advocate for the marginalised against the powerful platforms and attempt to "make [target users] aware of [potential] injustices and to encourage debate and discussion on these issues" (West et al., 2012:1586). In some instance, these issues are already evident without extended discussions, for instance, many individuals refuse to sign up on different platforms citing various reasons including concerns of privacy.

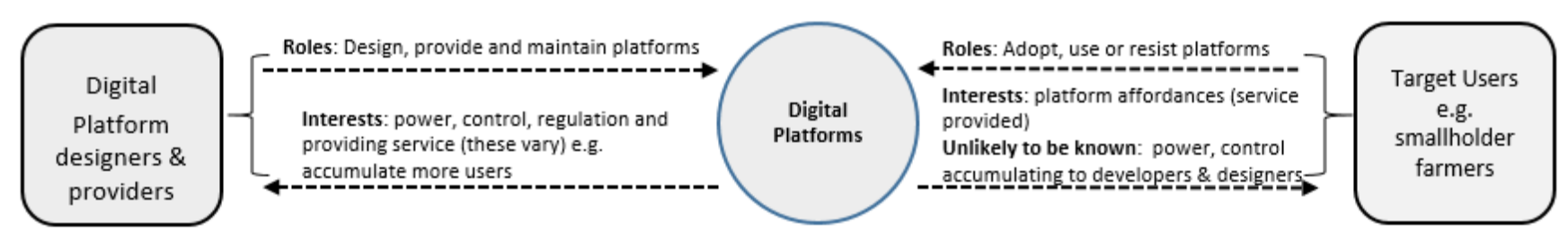

Figure 2. Conceptual framework of digital platforms

The conceptual framework and critical thinking had implications on the study. Firstly, the question asked in this study, amid ongoing adoption and upscaling of digital platforms, was premised on the need to achieve a balanced assessement of the platforms' potential. In essence, the potential of digital platforms was explored beyond the simplistic positive and negative effects to also include issues of power and authority. Secondly, the data used in this study was purposively selected to ensure that only data which emerged from activities in which the researchers and research participants were equals (equal input and respect of views). Thirdly, the research methods included dialogue, deep listening and ongoing reflection. This was important to achieve an understanding of "what society could become" and "not what it is" Fuchs (2009:71). We developed the research methods - i.e., community visioning exercises with a critical thinking perspective which aims to empower "community members and research participants to take control of their futures" (West et al., 2012:1585-1586).

\section{METHODOLOGY}

The integration of digital platforms into value chains such as the livestock system, is a complex process. To study this, Geoff Walsham advocates for critical thinking particularly to "[challenge] existing orthodoxies and hierarchies" (Walsham, 2012:89). This study originated from a broader project in the 
study area (see also, Gwaka, 2017) on the integration of ICTs in livestock systems. The project hypothesized that introducing ICTs could help overcome challenges within the livestock value chain. ${ }^{4}$

\section{Data collection}

To obtain insights on the state of the livestock system and the potential of digital platforms, empirical data were gathered between 2015 and 2018 in four purposively selected villages in Ward 15 of Beitbridge district, Zimbabwe. Ethical clearances for the study were obtained from the university ethics committee while at local level, the local authorities (administrative and traditional) provided community engagement clearances for the study. The sequence of data collection activities was based on Fine's (2003) suggestion that the process of ethnographic work should move from descriptive (how) to analytical (why). As such, in this study, the field activities started with participant observations in community gatherings such as livestock auctions. This allowed researchers to develop deeper insights on the livestock system dynamics. During the study, the researchers attended livestock auctions $(n=11)$ observing the process of livestock sales (see, Figure 3) which includes bidding, negotiation and transacting. Participant observation helped to develop insights on the complexities such as power dynamics during livestock sales, related challenges and identify potential opportunities for integrating ICTs. Following this, we engaged the communities in community visioning workshops. The main aim of the community visioning exercises was to establish the state of livestock system which the community desires, wish for and willing to work towards. Using this foresight technique, the researchers also aimed to gauge the participants' interests to integrate available digital platforms within the livestock system. Further, additional data were gathered through interviews as well as focus group discussions. The final stage of data collection was through a household survey questionnaire which was administered by locally recruited research assistants.

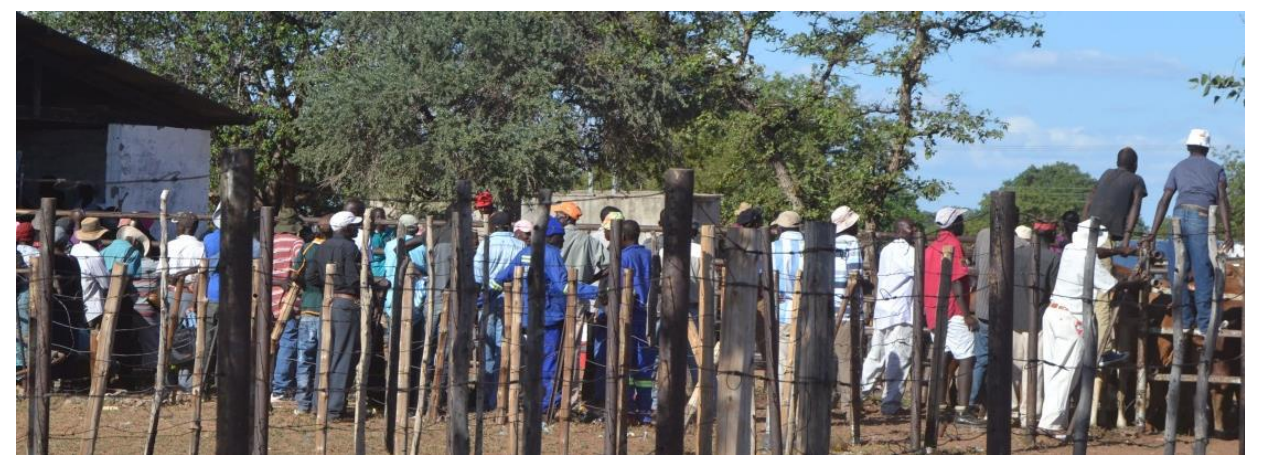

Figure 3. Participant observation at a livestock auction in Ward 15

\section{Instrument development}

Since the study adopted a mixed method approach, data collection was achieved using multiple research instruments. Quantitative data were obtained using a household survey questionnaire while qualitative data were obtained using focus group discussion guide, interview guide and participatory research agenda. Consistent with the critical theory approach, the qualitative research instruments and activities were designed to ensure reciprocity, deep listening and observations, as well as equal participation (cf.

\footnotetext{
4 See here; Mobile Solutions for Marginalised Communities (MOSMAC) Innovation. Retrieved July 28, 2019 from http://sarilab.ranlab.org/content/mobile-solutions-marginalised-communities-mosmac-innovation
} 
West et al., 2012). For instance, during livestock auctions (participant observation), researchers ensured that they had uninterrupted observations and then in some cases, observed the process as part of a group. The interview guides provided probing questions (e.g. in addition to preferences (or not) of specific digital platforms, interviewees were asked to further motivate their responses), while the focus group discussion guide provided for opportunities for intensive interaction and deep listening. To develop these, the researcher relied on previous related studies' instruments, research gaps identified in other studies and the research question set for the study. For community visioning, the researchers developed an agenda for each session which was used to guide the activities. However, other discussions emerged during the visioning exercises and the researchers used their discretion on whether to pursue the new topic or not. The agenda was often a culmination of data gaps identified during the preliminary analysis conducted simultaneously with data collection as well as topic suggestions from the community.

Quantitative data for the study were collected using a household survey questionnaire. In designing the questionnaire, recommendations (e.g. types of questions) from several guidelines were adopted. The household survey questionnaire was also prepared after several community engagements which helped to generate appropriate questions. The questionnaire consisted of 67 questions in six sections as follows: General household information (5); Household demographics (7); Household assets (with sub-questions) (9); Household livelihood activities (10); Household food system (with sub-questions) (10) and Digital infrastructure and ICTs (26). To improve the nature of data collected for the study, the question types were diversified to include lists, closed questions, quantities, category questions and ranking questions (cf. Marshall, 2005). However, despite the variations of question types, these questions were developed to support the primary research question and related sub-questions. Pilot testing of the questionnaire was conducted before the final administration.

\section{Data analysis}

In a mixed methods study, data analysis, like data collection, is also conducted using mixed approaches. In this study, since both qualitative and quantitative data were collected, data analysis was also completed using qualitative and quantitative data analysis techniques. For quantitative data, the desired precision was $95 \%$ with the desired confidence interval of 5 which means the significance threshold was set at 0.05 with p-values $<0.05$ considered significant.

\section{Qualitative data analysis}

The study employed different ethnographic methods which yielded different types of qualitative data sets including field notes, recordings, photographic evidence, diagrams and maps. The process of data analysis started immediately while in the field allowing the processes of data collection and analysis to be completed concurrently. As a result, we could identify the gaps within the data and dedicate more effort towards the missing data. The process of qualitative data analysis started with data cleaning. From the data gathered, other data sets had problems including incompleteness (e.g. incomplete notes not making sense), community notes (poorly written), incomplete recordings (less than 60 seconds) and even hazy photographs. Incomplete data sets were either included after going back to the community to clarify (on incomplete data) and reconstruction or excluded. Once data sets were cleaned, theme development started. The process of developing themes was cyclical but consisted of four major phases (Vaismoradi et al., 2016). The process started with initialisation to capture participants' accounts which included transcribing recorded sessions such as focus group discussions and interviews. At this stage, researchers carefully listened, in most cases, repeatedly, to the audio recordings collating data notes in 
Word documents. The notes on different charts made during the various sessions (e.g. community visioning workshops) were also transcribed. Based on literature, reflections on the field activities and thematic analysis of data, themes were identified relating to the research focus. The process of developing themes included defining, labelling, classifying and comparing the data. Further to this, established themes were related and the story presented in the results section was developed. To ensure the validity of the findings, the researcher conducted a findings confirmation (feedback) session with the respondents.

\section{Quantitative data analysis}

Quantitative data generated from the questionnaires were analysed using the SPSS statistical package version 25. From the 270 questionnaires distributed, 46 were discarded from the analysis for various reasons mainly that the quality was deemed too poor to use; and in some cases, were there were suspicions of fabrication of data. Of the remaining 224, data were captured using Kobo toolbox, cleaned and organised before subsequently being converted to CSV format for analysis using SPSS software. Statistical analysis assistance was received from a qualified statistician. A discussion with the statistician was critical in providing direction for the data analysis. For instance, the statistician needed guidance on the relationships to analyse. From the analysis, the data generated included univariate analysis (frequencies, means, percentages, graphs, charts) and multi-variate analysis (relationships)

\section{RESULTS}

In this section, the study presents empirical findings based on the two main themes which emerged from the analysis which are livelihoods in rural areas and ICTs in rural areas. The sub-themes for livelihoods in rural areas are livestock, natural resources and informal trading. On the other hand, sub-themes for ICTs in rural communities are ICT access and use (including digital platforms) and connectivity (networks/infrastructure). Livestock, a sub-theme of livelihoods, is central to the livelihoods of the households thus, is the focus of this study. Before presenting the findings on the selected themes, the study presents demographic information using Table 2. Following this, the focus is shifted to livestock's importance to the community and the challenges faced by the smallholders, particularly relating to livestock auctioning. Following this, the study shifts to present findings on ICTs in rural communities specifically focusing on the potential of digital platforms in the livestock system.

\section{Demographic findings}

The livestock system comprises of different groups of actors who take on different responsibilities. Digital platform designers and providers are also becoming part of the livestock system through appropriation of digital platforms into the livestock systems. During this study, the researchers engaged with different groups of stakeholders including smallholder farmers, local authorities, local leaders, government departments and representatives of different groups. Further, the researchers attempted to engage with digital platforms developers but this was challenging. For instance, other developers declined to discuss about their business. In table 2, the study presents a detailed breakdown of the demographics showing the engagement activities and the type of data collected during these engagements. 


\begin{tabular}{|c|c|c|c|c|}
\hline Period & Activities & Data Collection & Participants & Summary demographics \\
\hline $2015 / 16$ & $\begin{array}{ll}\text { - } & \text { Community } \\
\text { entry } \\
\text { - } & \text { Community } \\
\text { meetings } \\
\text { - } & \text { Livestock } \\
\text { auction visits }\end{array}$ & $\begin{array}{lr}\text { - Qualitative } & \text { data } \\
\text { obtained include key } & \text { insights on community } \\
\text { structure, } & \text { livestock } \\
\text { system } & \text { structure, } \\
\text { photographs } & \text { and } \\
\text { observation of } & \text { system } \\
\text { dynamics } & \end{array}$ & $\begin{array}{l}\text { - All stakeholders } \\
\text { involved in the } \\
\text { livestock system } \\
\text { including } \\
\text { smallholder farmers. }\end{array}$ & 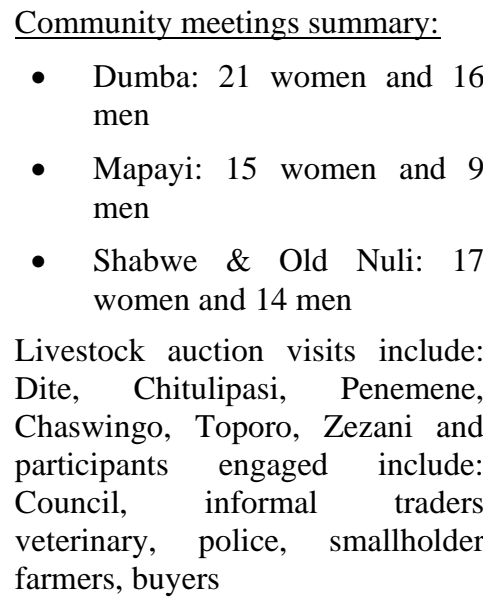 \\
\hline $2016 / 17$ & $\begin{array}{ll}\text { - } & \text { Household } \\
\text { survey } \\
\text { questionnaire } \\
\text { - } & \begin{array}{l}\text { Focus group } \\
\text { discussions }\end{array} \\
\text { - } & \text { Interviews }\end{array}$ & $\begin{array}{lr}\text { - } \begin{array}{l}\text { Quantitative } \\
\text { obtained }\end{array} & \begin{array}{r}\text { data } \\
\text { from } \\
\text { household } \\
\text { questionnaires }\end{array} \\
& \text { (From } \\
270 \text { questionnaires, } 224 \\
\text { were correctly } \\
\text { completed and used for } \\
\text { data analysis) } \\
\text { - } \begin{array}{l}\text { Qualitative data } \\
\text { obtained from } \\
\text { and interviews }\end{array}\end{array}$ & 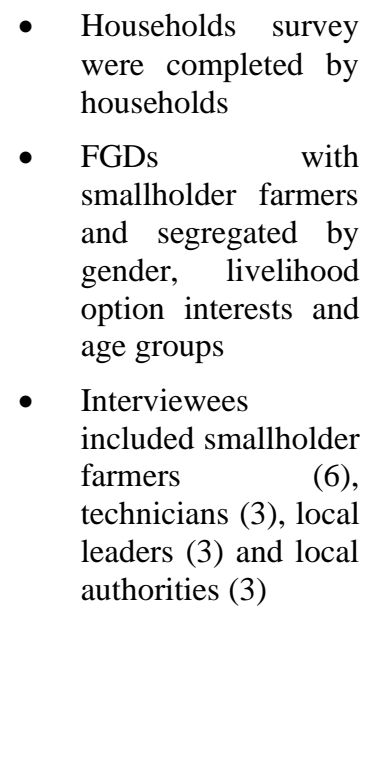 & $\begin{array}{l}\text { Focus Group Discussions } \\
\text { - } \quad \text { Dummary: } \\
\text { - } \quad \text { Mapayi: } 2 \text { women and } 7 \text { men } \\
\text { - } \quad \text { Shabwe \& Old Nuli: } 4 \text { women } \\
\text { and } 13 \text { men } \\
\text { Summary of interviews: } \\
\text { - } \quad 8 \text { Smallholder farmers } \\
\text { - } \quad 5 \text { Government departments } \\
\text { e.g. education, Department of } \\
\text { livestock production and } \\
\text { development, ministry of } \\
\text { information } \\
\text { - } 1 \text { Association Representative } \\
\text { 1 Traditional leader }\end{array}$ \\
\hline $2017 / 18$ & $\begin{array}{ll}\text { - } & \text { Intervention } \\
\text { implementatio } \\
\mathrm{n}\end{array}$ & $\begin{array}{l}\text { - Community insights on } \\
\text { ICTs } \\
\text { - Qualitative } \\
\text { confirmation of study } \\
\text { findings }\end{array}$ & $\begin{array}{l}\text { - All stakeholders } \\
\text { involved in the } \\
\text { project }\end{array}$ & $\begin{array}{l}\text { - All stakeholders involved in } \\
\text { the project }\end{array}$ \\
\hline
\end{tabular}

Table 2. Summary of data collection and demographics of research participants

\section{Livestock and livelihoods in Beitbridge}

The livelihoods of households in Beitbridge revolve around livestock, natural resources and informal trading (linked to the Beitbridge border). Despite the existence of other livelihood options, study findings indicate that livestock remain the perennial source of income. Households own large herds of livestock e.g. (cattle, $\mathrm{X}(n)=59 ; \mathrm{SD}=6.4$ ) and these are central to the livelihoods of these households. 
Livestock is used in many ways and respondents indicated that holding large livestock was motivated by socio-cultural and economic needs for instance, as investment and risk management strategy (cf. Quinlan et al., 2016). The study found significant differences between livestock use - i.e. (selling $\mathrm{p}=$ 0.007; investments: $\mathrm{p}=0.01$ and food: $\mathrm{p}=0.01$ ) and village. Overall, participants stressed the importance of livestock as one participant highlighted that:

In our area, livestock rearing is an inherited culture from our forefathers and livestock has many crucial functions. We keep livestock for selling to cater for household expenses. We also slaughter cattle on special occasions such as weddings and use livestock for cultural activities. Having large herd of livestock also gives social status (prestige) (Young Male, Mapayi focus group discussion)

While livestock is central to the livelihood of the households in the study area, the livestock system is characterized by many challenges. Some of the challenges identified include poor infrastructure (roads and auction facilities), information asymmetries, limited buyers and poor coordination among the governance institutions. These challenges have intensified since the collapse of CSC as one workshop participant indicated that:

"We face many challenges relating livestock and since the collapse of the Cold Storage Commission, we have never had satisfactory buyers. Also, there is limited government support towards livestock production e.g. there are fewer technicians who have limited resources and cannot reach all villages especially when there is disease breakouts" (elderly male, community meeting)

In addition to system-specific challenges, macro-economic challenges such as cash shortages and price instability within the country also affect the process of livestock buying and selling. In the context of environmental challenges, climate change is contributing towards livestock deaths and poor livestock quality. This was further worsened by a lack of insurance options for the smallholder farmers. One farmer, reflecting on the prices fetched during livestock auction, expressed his frustration that:

"We literally give away our livestock to the buyers. These buyers pay us very poor prices and drive livestock to Bulawayo and Masvingo where they fetch very high prices. Unfortunately, we don't have the resources (transport), nor can we self-organise, to take our livestock to these high-paying markets" (elderly male, Lutumba auction)

From the community engagements and observations, there are many other challenges which the respondents did not raise. For instance, during the auction, farmers lacked market information and bargaining techniques. Most farmers based their prices on historical sales as well as comparing to what other farmers were accepting on the day. Through a comprehensive livestock system review, the study identified challenges relating to governance such as outdated policies which contribute to the fragility of the livestock system. The challenges highlighted above are not unique to Beitbridge, nor are they recent. Efforts to overcome these challenges include the integration of digital platforms but the success of these interventions remains somewhat unclear.

\section{Digital platforms and livestock systems}

There are several digital platforms which have been developed and can be used by livestock system actors to overcome some of the challenges discussed above. In Table 3, we explore these digital platforms, their affordances, acceptance and/or rejection in Beitbridge. From the engagements with the communities, it was evident that the main concern among the respondents was the realization of optimal returns from their livestock. Respondents argued that there is an urgent need to address challenges 
contributing to poor livestock pricing and these relate to livestock marketing, information access, infrastructure and linkages between buyers and farmers. At the time of the study, it was established that there are digital platforms designed with affordances to address the different challenges and other platforms, specifically the Remote Livestock Marketing System (RLMS) (Figure 4) promised to provide solutions to most challenges. As indicated on their website, the RLMS aims to enable livestock farmers to sell their livestock in the "comfort of their homes" (RLMS, online). It seeks to achieve this by creating virtual meeting place for buyers and sellers overcoming distance and infrastructure constraints. In doing so, the platform promises to widen access to alternative markets for both buyers and sellers.

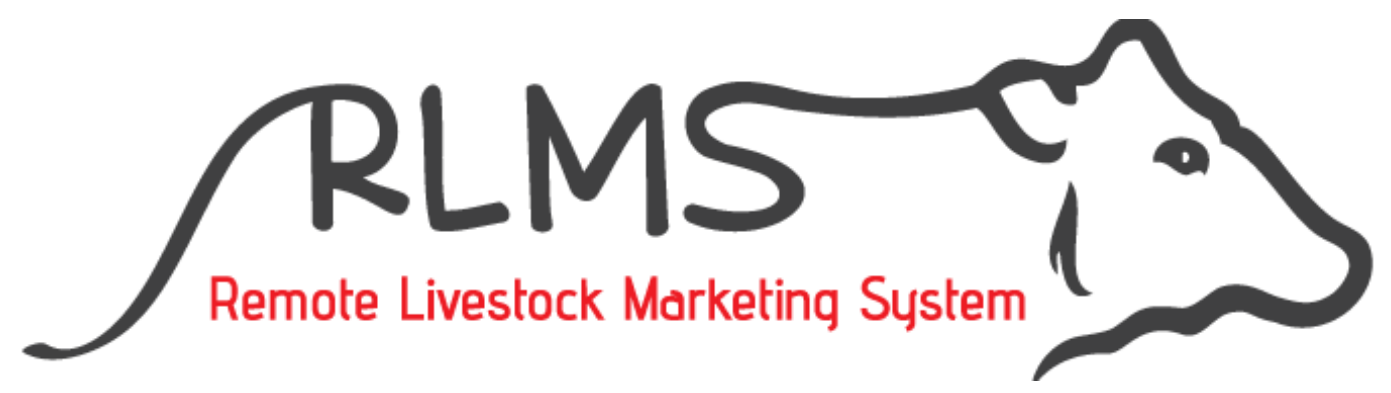

Figure 4. The Remote Livestock Marketing System Logo

Source: RLMS (online)

While RLMS promises to provide a range of services, there are also other platforms which provide different services. For instance, Kurima Mari is another relevant platform and according to Chaparadza (2018) "the app provides farmers with various information concerning crops, livestock, nutrition, financial services (for agriculture business), selling tips and the market for buyers and sellers. All that information can be read by many people in [Zimbabwe] as the app can be used in three different languages, English, Shona, and Ndebele" The Esoko and eMkambo are similar platforms which have been developed to help farmers receive agricultural and market information.

In addition to agriculture-specific platforms, the study also found that social network platforms such as Facebook and WhatsApp are also used in the livestock system. WhatsApp was popular among the farmers as these farmers create groups to self-organise and share information in different formats e.g. text, images, audios and videos. Social media platforms are also being used by livestock buyers as well as livestock technicians. One technician highlighted that:

"We are already using other technologies and we are seeing the benefits such as a reduction in trips we have to make to the field. If other relevant technologies become available, we will embrace these and even teach the farmers as this will simplify our work" (livestock technician, Old Nuli village)

Our assessment of the digital platforms available to the livestock actors suggest that there is an increase in platforms designed by local people but there remains a design-reality gap in that most platforms available continue to disregard context. 


\begin{tabular}{|c|c|c|c|}
\hline Platform & Affordance & $\begin{array}{l}\text { Applicability to the livestock } \\
\text { value chain }\end{array}$ & $\begin{array}{l}\text { Use or adoption in the study } \\
\text { area }\end{array}$ \\
\hline RLMS & $\begin{array}{l}\text { Allows buying \& selling } \\
\text { in the comfort on one's } \\
\text { home }\end{array}$ & $\begin{array}{l}\text { Facilitate the virtual meeting of } \\
\text { buyers \& sellers, thus, provide } \\
\text { alternative markets and increase } \\
\text { number of buyers }\end{array}$ & $\begin{array}{l}\text { Not adopted and farmers not } \\
\text { aware. However, there were } \\
\text { indications of the system being } \\
\text { used in areas such as Rushinga. }\end{array}$ \\
\hline E-Mkambo & $\begin{array}{l}\text { A market -driven } \\
\text { agricultural solution } \\
\text { platform- facilitating } \\
\text { Price distribution }\end{array}$ & $\begin{array}{l}\text { Facilitate timely access to market } \\
\text { trends and market information by } \\
\text { farmers thereby impact the } \\
\text { decision-making process and } \\
\text { negotiation process }\end{array}$ & $\begin{array}{l}\text { Not adopted and farmers not } \\
\text { aware. Also, the system } \\
\text { currently mainly focuses on } \\
\text { other agricultural commodities. }\end{array}$ \\
\hline Ecocash & $\begin{array}{l}\text { Mobile money service } \\
\text { including making and } \\
\text { receiving payments }\end{array}$ & $\begin{array}{l}\text { In the context of Zimbabwe, the } \\
\text { platform helps to overcome cash } \\
\text { shortage and, can be used as a } \\
\text { saving option by farmers without } \\
\text { bank accounts }\end{array}$ & $\begin{array}{l}\text { Adopted by some, others have } \\
\text { rejected it (especially during } \\
\text { cash crisis) }\end{array}$ \\
\hline $\begin{array}{l}\text { Social networking } \\
\text { sites } \\
\text { e.g. Facebook }\end{array}$ & $\begin{array}{l}\text { Information generation } \\
\text { and distribution }\end{array}$ & $\begin{array}{l}\text { Facilitating discussions among } \\
\text { livestock system actors. }\end{array}$ & $\begin{array}{l}\text { Adopted by some, others have } \\
\text { rejected it for personal reasons. }\end{array}$ \\
\hline
\end{tabular}

Table 3. Digital platforms which can be adopted by livestock farmers

As Table 3 shows, not all available digital platforms have been adopted by livestock actors in the study area. In this study, at least $84 \%$ of the survey respondents $(n=224)$ had access to mobile phones but when respondents were asked whether they had used the available platforms, findings show that at least $33 \%$ and less than 1\% had used the Ecocash platform and any social networking platform, respectively. Explanations supporting these findings including lack of knowledge, costs of using mobile phones and the type of mobile phone handset used (most individuals own feature phones).

When asked if they had any concerns regarding digital platforms, respondents highlighted issues of costs and privacy. The responses obtained also suggest that there is an inherent lack of trust in digital platforms demonstrated by concerns such as "I don't know what they will do with my information" Also, there were muted concerns on the complex issues which, unfortunately, respondents were not able to clearly point. For instance, one farmer who rejected Ecocash payment argued that:

Ecocash is ripping us. We are just making the company rich as I must pay extra charges to access my own money. Sometimes when I want my money, I can't access it because their network will be down. I would rather wait until there is cash.

In addition to this, the study also found that the value proposition of digital platforms conflicted with sociocultural dynamics of the community. For instance, online livestock sales suggest that farmers can complete transactions (advertising and selling livestock) in the comfort of their homes, but in the study area, livestock-related events are part of the sociocultural dynamics. Thus, when asked how they feel about the value propositions of digital platforms during a focus group, one respondent refuted the idea of virtual auctions arguing that:

While I like the idea of selling livestock in the comfort of my home, going to the show has become part of our lives. We go there not only to sell livestock but also to interact with others and even show off our wealth. That is the reason why it takes the whole week. In addition, there is always 
the band playing after showa. So, these technologies might really disrupt all these activities if we are not careful (Elderly male, Dumba)

\section{DISCUSSION}

The purpose of this study was to investigate the potential of digital platforms to revitalize the livestock system in rural areas. Incidentally, the study appears to respond to Chaparadza's (2008) article titled: Digital livestock market: an idea whose time has come? As a starting point, the study considered the importance of livestock system to the study area and moved on to identify the challenges facing the livestock system. This was followed by exploring the digital platforms available which can be or are being used to overcome these challenges.

In terms of livestock's importance, the study findings show that households perceived livestock to play significant roles, including towards food (access and availability), household income and other social roles. These findings are also reported in key reports including CFS and FAO. The study's characterisation of the livestock system - as a fragile system, with poor infrastructure and poor returns for farmers - has also been reported in other studies (Mavedzenge et al., 2008; Quinlan et al., 2016). Worryingly, Mavedzenge et al.'s (2008) observation that livestock infrastructure in rural communities is inadequate, remains the same in many rural areas visited during this study. This has intensified calls for transformation of livestock systems (Barrett et al., 2017) and responses include interventions such as the MOSMAC project in Beitbridge to introduce ICTs, including digital platforms. But as always, it remains unclear whether interventions can deliver the desire changes (Oliver et al., 2018). Thus, de Reuver et al. (2017) suggest focusing on establishing the potential of these digital platforms to disrupt systems.

Relating to digital platforms available, which can potentially be adopted within the livestock systems, the study identified digital platforms available for use within the livestock system. Among these platforms, some were developed specifically for agriculture-related purposes, while others were developed for different purposes but repurposed for agriculture. On technology affordances, we anticipated that digital platforms can provide alternative solutions to prevailing challenges (e.g. poor markets) and this is also reported in other studies on digital platforms' affordances such as Andersson Schwarz (2017) who expect digital platforms to open up markets. Onono, Amimo and Rushton (2015) also observed that smallholder farmers in rural areas are being attracted by the technology affordances (e.g. the idea of online markets). Another key observation of the study relates to digital platforms' repurposing which related to adoption of digital technologies for valuable use across contexts (Antonopoulou, Nandhakumar \& Henfridsson, 2016). The study found that social media platforms, including Facebook, are being used for activities such as livestock marketing and provide critical affordances, such as instant messaging and content sharing. However, despite the increase in digital platforms available, the study findings, in line with Chaparadza's (2018) observation, suggest that there are several gaps within the livestock system for future innovation.

In terms of the developers and providers, digital platforms available to the rural communities are designed outside the user-communities, with limited consultation of the target users, by individuals whose understanding of the local systems, in most cases, is extremely limited (cf. Ornetzeder \& Rohracher, 2006). This results in what Heeks (2003) point to as the design-reality concept which suggest that the design of digital platforms fails to accommodate the reality of the end users. The study noted an increase in local innovators e.g. eMkambo and Maxifarm are innovation developed by local Zimbabweans. However, as Bharadwaj, Sawy, Pavlou and Venkatraman (2013:48) argue, "the value 
capture involves complex coordination between app developers, the mobile OS (Apple, Android, Windows, or Blackberry), hardware manufacturers, telecom operators, and service providers such as Facebook, YouTube, and others. The complicating factor is that the business models are not independent but intersect and interoperate across these different players" In addition to these complex interactions, the study further noted that emerging digital platforms attract considerable funding and some innovators are seeking to enrich themselves. Therefore, it remains challenging to accurately determine the interests of developers and providers, particularly those which aggravate inequality. Considering global ethics scandals such as Facebook and Cambridge Analytica, it is prudent to be concerned about the interests of the digital platform providers. Dourish and Mainwaring (2012:1) argue that, "colonialism is a much more pervasive aspect of ubiquitous computing than we normally give it credit for. In fact, it is entwined with all sorts of aspects of how we think, how we talk, and how we work" To this end, the study argues that it if not far-fetched to think of digital platforms as modern tools to amass power and control in society as William's (2015) observation that, "in each era power must be refashioned in the image of its age".

Moving on to the target users, the study shows that this group has the choice to accept or reject digital platforms which are available to them. The study noted that there were differences in attitudes and perceptions towards digital platforms as well as inequitable access to connectivity and data. Despite cash shortages during the study, farmers rejected the Ecocash payments and this rejection of mobile services in agricultural systems was also noted in Wyche and Steinfield (2016). In addition, the adoption and use of the available digital platforms varied, with a few farmers reporting positive experiences. On the other hand, buyers and livestock technician reported growing use of digital platforms with suggestions on how new platforms they look forward to in future. It appeared that individuals with more resources (e.g. better education, mobile phones) benefit more from digital platforms than those with limited resources (e.g. others could not afford data). Thus, instead of digital platforms contributing towards sustainable and equitable livestock systems, they potentially "reproduce the inequalities" among the system actors (Leurs \& Zimmer, 2017:807). Thus, actors with the livestock system who already have resources (access to smartphones and can afford data) will continue to benefit from digital platforms, and accumulate more resources, while those with limited resources continue to face challenges (Wyche, Simiyu \& Othieno, 2016)

\section{CONCLUSION}

This study has explored the potential of digital platforms in revitalising the livestock system in rural communities in Zimbabwe. Based on the findings on the state of the livestock system in Beitbridge and the affordances of various digital platforms, both designed specifically for livestock system and not, the study concludes that digital platforms have the potential to revitalize the collapsing livestock system. We argue that digital platforms create new digital products and services (e.g. virtual markets, mobile payments, mobile insurance and instant messaging among others) which, if correctly appropriated, can contribute towards overcoming the complex challenges faced within the livestock system. Through new products and services, digital platforms can also transform the structure of the livestock system for example, through changing information sharing channels, attracting new actors (opening and widening markets). While different digital platforms are developed with specific affordances, it is essential that individuals are aware and willing to utilise these. Nonetheless, the failure of livestock system actors to recognise digital platforms' affordances does not translate to digital platforms being unable to play a role within livestock systems. 
In addition, the study also concludes that while digital platforms have the potential to play a role towards improving livestock systems, they are fraught with hidden complexities. Specifically, the study argues that the interests (value capture) of platform developers and designers are complex, and often hidden. In this way, deeper structural issues such as power dynamics, capitalism and social injustice are not evident to target users. This means, to be certain on the potential of these digital platforms, it may be essential to also draw from non-technical subjects e.g. sociology and philosophy of technology, a lens commonly applied in the work of Susan Leigh Star and Geoffrey Bowker. However, the study suggests that, in the interest of social justice, it would be amiss to promote, adopt and use digital platforms without clear insights on the interests of digital platforms' designers and service providers.

Therefore, given the foregoing summaries, we clarify that digital platforms have the potential to revitalize the livestock system. However, to the achieve desirable outcomes, target users need detailed information, pros and cons, to enable them to make informed decisions on whether to adopt or reject these platforms. It also follows that developing countries need to establish and enforce regulation on the emerging digital platforms if social justice is to be achieved through technological innovations.

\section{RECOMMENDATION}

This study has identified the potential of digital platforms in revitalising the livestock system in rural areas and noted concerns with the use of these digital platforms. From the conclusions drawn above, the study recommends a gradual approach towards the integration of digital platforms within the livestock system. Coupled with this, ongoing critical assessment, particularly weighing value proposition against value capture, by third parties may be needed, to achieve social justice. In the same vein, the study recommends collaborative design of digital platforms and intensifying discussions on the potential threats of digital platforms. It is incumbent upon the research community, using interdisciplinary approaches and teams, to objectively explore the emerging and existing platforms which are being integrated in the local value chains and develop recommendations on whether these platforms work or not, towards solving societal problems. In terms of future work, it is suggested that future research on digital platforms can focus on establishing the digital platforms being or which have the potential of being integrated in other rural value chains. Comparative studies on platforms' compatibility within different systems e.g. digital platforms for health vis-à-vis digital platforms for education can be critical in providing researchers with additional insights on digital platforms' potential. Also, engaging with different individuals at different levels within the platform design and development can also provide new information on the interests and motivations for platform designers and providers. Further to this, future studies can utilise creative techniques such as positive deviance to analyse 'successful' digital platforms to understand the contextual factors towards the success.

\section{ACKNOWLEDGMENTS}

We thank the ResilientAfricaNetwork (Makerere University), SARILab (University of Pretoria) for providing financial and technical support. We thank Professor Salah Kabanda for her constructive comments on the previous version of the paper. 


\section{REFERENCES}

Aker, J. C., \& Fafchamps, M. (2010). How does mobile phone coverage affect farm-gate prices? Evidence from West Africa. Department of Economics and the Fletcher School, Tufts University.

Andersson Schwarz, J. (2017). Platform Logic: An Interdisciplinary Approach to the Platform-Based Economy. Policy \& Internet, 9(4), 374-394.

Antonopoulou, K., Nandhakumar, J., \& Henfridsson, O. (2016). Creating new value through repurposing digital innovations. In Academy of Management Proceedings (Vol. 2016, No. 1, p. 16457). Briarcliff Manor, NY 10510: Academy of Management.

Avgerou, C. (2010). Discourses on ICT and development. Information Technologies \& International Development, 6(3), pp-1.

Avgerou, C., Hayes, N., \& La Rovere, R. L. (2016). Growth in ICT uptake in developing countries: new users, new uses, new challenges. Journal of Information Technology, 31, 4, 329-333.

Avram, G., Choi, J. H. J., De Paoli, S., Light, A., Lyle, P., \& Teli, M. (2017, June). Collaborative economies: From sharing to caring. In Proceedings of the 8th International Conference on Communities and Technologies (pp. 305-307). ACM.

Barrett, C. B., Christian, P., \& Shiferaw, B. A. (2017). The structural transformation of African agriculture and rural spaces: introduction to a special section. Agricultural Economics, 48(S1), 5-10.

Barrett, M., Oborn, E., \& Orlikowski, W. (2016). Creating value in online communities: The sociomaterial configuring of strategy, platform, and stakeholder engagement. Information Systems Research, 27(4), 704-723.

Bharadwaj, A., El Sawy, O. A., Pavlou, P. A., \& Venkatraman, N. (2013). Digital business strategy: toward a next generation of insights. MIS quarterly, 471-482.

Burrell, J., \& Oreglia, E. (2015). The myth of market price information: mobile phones and the application of economic knowledge in ICTD. Economy and Society, 44(2), 271-292.

Chaparadza, A. (2018). The Kurima Mari mobile app is for you if you are into farming. Retrieved September 18, 2019 from: $\quad$ https://www.techzim.co.zw/2018/10/the-kurima-mari-mobile-app-is-very-useful-if-you-are-in-theagriculture-sector/

Choi, J.H.-J. \& Graham, M. (2014). Urban Food Futures: ICTs and Opportunities. Futures, 62, B, 151-154.

CFS: Committee on World Food Security. (2016). Sustainable Agricultural Development for Food Security and Nutrition: What Roles for Livestock? Retrieved May 8, 2018 from http://www.fao.org/3/a-ms023e.pdf

Crain, C. (2013). Living in a society of control. Retrieved December 21, 2018 from http://www.mantlethought.org/philosophy/living-society-control

De Reuver, M., Sørensen, C., \& Basole, R. C. (2018). The digital platform: a research agenda. Journal of Information Technology, 33(2), 124-135.

Deleuze, G. (1992). Postscript on the Societies of Control. October, 59, 3-7.

Dourish, P., \& Mainwaring, S. D. (2012, September). Ubicomp's colonial impulse. In Proceedings of the 2012 ACM Conference on Ubiquitous Computing (pp. 133-142). ACM.

Fine, G. A. (2003). Towards a peopled ethnography: Developing theory from group life. Ethnography, 4(1), 41-60.

Fuchs, C. (2009). Information and communication technologies and society: A contribution to the critique of the political economy of the Internet. European Journal of Communication, 24(1), 69-87.

Fuchs, C., \& Sevignani, S. (2013). What Is Digital Labour? What Is Digital Work? What's Their Difference? And Why Do These Questions Matter for Understanding Social Media? tripleC: Communication, Capitalism \& Critique 11 (2): 237-293.

Gaver, W. W. (1991, April). Technology affordances. In Proceedings of the SIGCHI conference on Human factors in computing systems (pp. 79-84). ACM.

Gwaka, L. T. (2017). Digital Technologies and Sustainable Livestock Systems in Rural Communities. The Electronic Journal of Information Systems in Developing Countries, 81(1), 1-24. 
Gwaka, L. T., May, J., \& Tucker, W. (2018). Towards low-cost community networks in rural communities: The impact of context using the case study of Beitbridge, Zimbabwe. The Electronic Journal of Information Systems in Developing Countries, e12029.

Harris, R. W. (2016). How ICT4D research fails the poor. Information Technology for Development, $22(1), 177-192$.

Heeks, R. (2003). Most e-government-for-development projects fail: How can risks be reduced? (Vol. 14). Manchester: Institute for Development Policy and Management, University of Manchester.

Heeks, R. (2014). Future Priorities for Development Informatics Research from the Post-2015 Development Agenda. (IDPM Development Informatics Working Papers No. 57). The University of Manchester.

Herald. (2017). Cash-rich middlemen rip off farmers. Retrieved October 27, 2018 from https://www.herald.co.zw/cashrich-middlemen-rip-off-farmers/

IFAD. (2016). Rural Development Report 2016: Fostering Inclusive Development, International Fund for Agricultural Development, Rome. Retrieved June 8, 2018 from https://www.ifad.org/documents/10180/4bcb3209-0773489a-b93a-57fae6581b69.

Ison, R.L., Maiteny, P.T. \& Carr, S. (1997). Systems Methodologies for Sustainable Natural Resources Research and Development. Agricultural Systems, 55, 2, 257-272.

Kazan, E. (2018). Towards a Disruptive Digital Platform Model (Doctoral dissertation, Copenhagen Business School $[\mathrm{PhD}])$.

Kleine, D. (2010). ICT4WHAT? Using the Choice Framework to Operationalise the Capability Approach to Development. Journal of International Development, 22, 5, 674-692.

Kuriyan, R., Nafus, D. \& Mainwaring, S. (2012). Consumption, Technology, and Development: The "Poor" as “Consumer". Information Technologies \& International Development, 8(1), pp-1.

Leurs, K., \& Zimmer, M. (2017). Platform values: an introduction to the\# AoIR16 special issue. Information, Communication \& Society, 20:6, 803-808, DOI: 10.1080/1369118X.2017.1295464

Lyytinen, K. J., \& Klein, H. K. (1985). 12 THE CRITICAL THEORY OF JURGEN HABERMAS AS A BASIS FOR A THEORY OF INFORMATION SYSTEMS.

Malekovic, N., Goutas, L., Sutanto, J., \& Galletta, D. (2019). Regret under different auction designs: the case of English and Dutch auctions. Electronic Markets, 1-11.

Marandure, T., Makombe, G., Dzama, K., Hoffmann, W., \& Mapiye, C. (2018). Towards a system-specific framework for the sustainability evaluation of low-input ruminant meat production systems in developing countries. Ecological Indicators, 85, 1081-1091.

Marshall, G. (2005). The purpose, design and administration of a questionnaire for data collection. Radiography, 11(2), 131-136.

Marshall, G. (2015). A social-ecological systems framework for food systems research: accommodating transformation systems and their products. International Journal of the Commons, 9(2).

Mavedzenge, B. Z., Mahenehene, J., Murimbarimba, F., Scoones, I., \& Wolmer, W. (2008). The dynamics of real markets: cattle in southern Zimbabwe following land reform. Development and Change, 39(4), 613-639.

Mlambo, A. S. (1996). The Cold Storage Commission: A colonial parastatal 1938-1963. Zambezia, 23(1), 53-71.

Mudombi, S. (2014). Analysing the contribution of ICTS in addressing climate change amongst communal farmers from two districts of Zimbabwe (Doctoral dissertation).

Mugandani, R., Wuta, M., Makarau, A. \& Chipindu, B. (2012). Re-Classification of Agro-Ecological Regions of Zimbabwe in Conformity with Climate Variability and Change. African Crop Science Journal, 20, 2, $361-369$.

Negash, S., Musa, P., Vogel, D., \& Sahay, S. (2018). Healthcare information technology for development: improvements in people's lives through innovations in the uses of technologies.

Nieborg, D. B., \& Poell, T. (2018). The platformization of cultural production: Theorizing the contingent cultural commodity. New Media \& Society, 1461444818769694.

Notenbaert, A., Pfeifer, C., Silvestri, S., \& Herrero, M. (2017). Targeting, out-scaling and prioritising climate-smart interventions in agricultural systems: Lessons from applying a generic framework to the livestock sector in subSaharan Africa. Agricultural systems, 151, 153-162. 
Oliver, T. H., Boyd, E., Balcombe, K., Benton, T. G., Bullock, J. M., Donovan, D., ... \& Nunes, R. J. (2018). Overcoming undesirable resilience in the global food system. Global Sustainability, 1.

Onono, J. O., Amimo, J. O., \& Rushton, J. (2015). Constraints and efficiency of cattle marketing in semiarid pastoral system in Kenya. Tropical animal health and production, 47(4), 691-697.

Ornetzeder, M., \& Rohracher, H. (2006). User-led innovations and participation processes: lessons from sustainable energy technologies. Energy Policy, 34(2), 138-150.

Ostrom, E. (2009). A general framework for analyzing sustainability of social-ecological systems. Science, 325(5939), 419-422.

Palaganas, E. C., Sanchez, M. C., Molintas, M., Visitacion, P., \& Caricativo, R. D. (2017). Reflexivity in qualitative research.

Patt, A., Suarez, P., \& Gwata, C. (2005). Effects of seasonal climate forecasts and participatory workshops among subsistence farmers in Zimbabwe. Proceedings of the National Academy of Sciences, 102(35), 12623-12628.

Prockl, G., Bhakoo, V., \& Wong, C. (2017). Supply chains and electronic markets-impulses for value co-creation across the disciplines. Electronic Markets, 27(2), 135-140.

Quaglio, G., Karapiperis, T., Putoto, G., Delponte, L., Micheletti, G., Brand, H., ... \& Zanaboni, P. (2016). Strengthening EU policies in support of ICT for development: Results from a survey of ICT experts. Health Policy and Technology, 5(4), 330-340.

Quinlan, R. J., Rumas, I., Naiskye, G., Quinlan, M., \& Yoder, J. (2016). Searching for Symbolic Value of Cattle: Tropical Livestock Units, Market Price, and Cultural Value of Maasai Livestock. Ethnobiology Letters, 7(1), 76-86.

Rey-Moreno, C. (2015). Community Telco: An acceptable solution for providing affordable communications in rural areas of South Africa. OMM Press.

Star, S. L. (1999). The ethnography of infrastructure. American behavioral scientist, 43(3), 377-391.

Täuscher, K., \& Laudien, S. M. (2018). Understanding platform business models: A mixed methods study of marketplaces. European Management Journal, 36(3), 319-329.

Temoso, O., Villano, R., \& Hadley, D. (2016). Evaluating the productivity gap between commercial and traditional beef production systems in Botswana. Agricultural Systems, 149, 30-39.

Thirtle, C., Lin, L., \& Piesse, J. (2003). The impact of research-led agricultural productivity growth on poverty reduction in Africa, Asia and Latin America. World Development, 31(12), 1959-1975.

Vaismoradi, M., Jones, J., Turunen, H., \& Snelgrove, S. (2016). Theme development in qualitative content analysis and thematic analysis. Journal of Nursing Education and Practice, 6(5), 100

Vanclay, F. M., Russell, A. W., \& Kimber, J. (2013). Enhancing innovation in agriculture at the policy level: The potential contribution of Technology Assessment. Land Use Policy, 31, 406-411.

van Doorn, N. (2018). The Parameters of Platform Capitalism. Retrieved October 26, 2018 from http://krisis.eu/nl/theparameters-of-platform-capitalism/

van Stam, G. (2017). Reflections: a narrative on displacement of technology and meaning in an African place

Vogt, F., Tayler-Smith, K., Bernasconi, A., Makondo, E., Taziwa, F., Moyo, B., ... \& Reid, A. (2015). Access to CD4 testing for rural HIV patients: findings from a cohort study in Zimbabwe. PloS one, 10(6), e0129166.

Walsham, G. (2012). Are we making a better world with ICTs? Reflections on a future agenda for the IS field. Journal of Information Technology, 27(2), 87-93.

Walsham, G. (2017). ICT4D research: reflections on history and future agenda. Information Technology for Development, 23(1), 18-41.

West, R., Stewart, L., Foster, K., \& Usher, K. (2012). Through a critical lens: Indigenist research and the Dadirri method. Qualitative Health Research, 22(11), 1582-1590.

Williams, A. (2015). Control societies and platform logic. New Formations, 84(84-85), 209-227.

Winner, L. (1980). Do artifacts have politics?. Daedalus, 121-136. 
Wyche, S., \& Steinfield, C. (2016). Why don't farmers use cell phones to access market prices? Technology affordances and barriers to market information services adoption in rural Kenya. Information Technology for Development, 22(2), 320-333.

Wyche, S., Simiyu, N., \& Othieno, M. E. (2016). Mobile phones as amplifiers of social inequality among rural Kenyan women. ACM Transactions on Computer-Human Interaction (TOCHI), 23(3), 14.

Wyche, S., \& Baumer, E. P. (2017). Imagined Facebook: An exploratory study of non-users' perceptions of social media in Rural Zambia. New media \& society, 19(7), 1092-1108. 